УДК 159.964

DOI: $10.26565 / 2410-1249-2019-12-03$

\title{
DESTRUCTION OF THE PSYCHE AND ITS LEVELING IN THE DEEP COGNITION
}

\author{
Tamara S. Yatsenko \\ A doctor of psychological sciences, professor, \\ Academician of the National academy of the pedagogical sciences of Ukraine, \\ The head of the chair of psychology, depth correction and rehabilitation \\ At the Bohdan Khmelnytsky national university of Cherkasy \\ Cherkasy (Ukraine) \\ E-mail: yacenkots@gmail.com,https://orcid.org/0000-0002-1996-661X
}

\begin{abstract}
Depth cognition of the psyche, performed while practicing psychodynamic understanding of the phenomenon of the psychic, can objectify a person's psyche destructions, caused by the dysfunctional relations in the family within the triangle: "father - child - mother". The abstract of the psychoanalysis presented in this article proves not only the role of the Oedipal dependences, which induce centrifugal force around the vicious circle, but also objectify the destructive consequences, which are expressed in a person's mental retardation, causing the balance violations between "the Libido" and "the Mortido" energies. The article objectifies the basic conflict "life-death" as well as the risks of its balance violation, which contributes to the development of the tendencies to importing the psyche and weakening the self-preservation instinct. The empirical evidence, presented in the article, verbally and vividly proves the interrelation of the depth aspects in their impact on the behavioral ones, which cause the psyche destructions, which need correction in the groups of ASPC.
\end{abstract}

KEY WORDS: depth psychological correction, ASPC, destructions, psyche, archaisms.

Problem statement. Destructions of the psyche can be not only generated by a person's unfavorable life conditions, but also they can be determined by the archaic heritage of the humanity: ability to sacrifice, striving to power (reign), underestimation of the other person's merits, tendency to suffering (masochistic inclination), guilt, the Oedipal dependences etc. Our long-term experience persuades that the platform of the family relations is often transformed into the battle place for the "Self" significances of the family people. It can make a child unfortunate and cause disfunctions and destructions of the psyche as dependent on the adults in the social, physical and soul aspects.

The goal of the article is to prove possible destructive consequences of the relations in the family, which arise out of control and conscious intentions of the family relations participants. This does not lessen risks of the mortido fixations and their consequential influences on a person's behavioral disfunctions.

The task of the article is to make an analysis of the humanity's archaic heritage with the aim to discover its influence on the extraexperiential psyche formations.

Presentation of the main material. Scientific generalizations of the 40-year research of the psyche depth-psychological parameters let us deepen the understanding of the unrealizable determinants, which are synthesized with the person's ontological acquirement including inherited universals, mutual for the whole humanity. Earlier we published the universal laws of the unconscious sphere functioning, which correspond to the laws of the Universe [0]. Efficiency of the archaisms has been known since the time of $\mathrm{S}$. Freud, namely they are objectified by the mechanisms of the dreams symbolism (compression, replacement, hint etc), which carry cognitive-universal meaning.

Research in the classical psychoanalysis is mostly based on free associations and dream interpretation, while psychodynamic research is oriented at the objective parameters of the psyche inner tendencies cognition with the condition that they are objectified by a person's conscious activity. The latter contributes to moving to the observation sphere of the latent factors, which are transformed into subjectified presentments, that has needed orientation at a person's self-activity if there is an introduction of the self-presentment indifferent means into the research process. General orientation of ASPC at a person's involuntary behavior set the necessity of back up harmonization to catalyze a person's spontaneity. It is about objectified means (stones, modeling, toys, psychological drawings, reproductions of the artistic works etc.), which 
contribute to receiving objective data, that minimizes their distortion by the defense system. It is important for the person not to be limited in selfcreativity while choosing visualized means, offered by a psychologist, for his/her own representation. During last decade alongside with the author's psychological drawings, a special significance is given to the reproductions of the artistic works. Their usage in depth cognition showed a peculiar ability to catalyze motivation in their combination with psychological drawings "Tattoo" (a person's own one and "tattoo of guilt"). According to our hypothesis "Tattoo" drawings contribute to synthesized presentation of the psyche in the combination of the ontogenetic and phylogenetic factors.

As for the usage of the reproductions of the artistic works (in the combination with the "Tattoo" drawings), we support C. Yung's point of view concerning art wakening a person's archetypical potential by the emotional breadth of his perception. We observe people's characteristic manifestations for the generalized perception by means of "pictures". To discover their semantics it is necessary to have dialogical psychoanalysis which reveals differentiation and ranking of the sense parameters for such a perception type. Doing quickly and easily the task of selecting reproductions for the self-presentment (taking into account the tattoo psychological drawings) indicates availability of a person's archetypical readiness and capability to recode the psychic as an ideal reality into the hypostatized one (observed plane of the objectified world). Physicist W. Pauli emphasized the importance of "the pictures - archetypes" for the scientific researches, thus he wrote: "In the development of the scientific ideas understanding is a complicated and long lasting process, which takes the rational formulation on the account of the previous processing of their contents in the unconscious". Archetypes play an organizational role in this. They are the necessary connection which connects sensual perception and ideas, and they are an important prerequisite for appearance of the natural-scientific concept (see $[0 ; 0]$ ).

In the depth cognition we observe merging of an individual's personal characteristics with the transpersonal, suprapersonal. Let's recollect E. Neumann's point of view, who wrote that “... a conscious person is a late product, whose structure has been built at the earlier personal stages of the humanity development, from which his consciousness has been separated step by step" [0]. In our opinion, this separation is directly involved to the transformations of the vivid-sensual perception into the verbal one.

S. Grof in his work "The Cosmic Game" mentioned that "it is important to take into account both prenatal and transpersonal its aspects" for understanding the psyche [0]. The idea of the space unity is also presented in the works of the famous Ukrainian scientist V. Tatenko: “... the psychic is considered as a microspace, which, according to its scales, intentions, potencies, and also hidden mysteries does not yield to and sometimes it even prevails over the space, carrying its image in itself" [0, p. 15]. Due to the mentioned we are convinced that a symbol is especially closely connected with an archetype, and hence there is an ability to objectify the hidden and unconscious, including motives, set by the archaic humanity heritage. The latter is synchronized with the opinion of the Psychology History classic V. Romanets $[0 ; 0]$. His ideas find their development in the works of the prominent Ukrainian psychologist A. Furman, which methodologically touch the following: realization of the world, its symbolic essence, which requires consideration of the available double nature; secret contents (except evident) of an action and thought, which induce to search the new ways for psychological cognition, as "the inner is hidden behind the outer, and truth is cognized by comparison of the opposites". Any people creates symbolic images, proving that a person may cognize down to the archetypical depths" [0, p. 19].

Thus, archetypes are interrelated with the symbolization of the humanity archaic heritage. The long-term experience persuades, that the archetypes, except visualization of a person's psyche contents, are able to objectify the logicality and order of his/her experience. The latter proves the archetypical ability to recode the ideal (psychic) reality into a hypostatized one.

Going to the depth parameters of the psyche, as our 40-year experience proves, needs to create the research platform, which involves the following: behavioral spontaneity and usage of the objectified forms of self-presentment, contributing levelling of the psyche subjectivism, which is set by the defense system and harms (by the perception deformation 
and understanding) of the person's adaptation process to the society. The results of our researches prove the availability of the psyche archetypical ability to recode the ideal psychic reality into the hypostatized one preserving the informational equivalents, which can be transformed into senses. We take into account the fact that the sense parameters of the psyche are inevitably connected with the unconscious, thus they can never be represented rectilinearly (by text) and, for sure, they need the research lasting in time, interpretational generalizations and correlation with each other via behavioural "steps", which in the combination contributes to understanding the sense meaning of a person's self-activity.

Our goal is to define the problem a person suffers, which is an unconscious (still stabilized) internal contradiction of the psyche. Objectification of the psyche destructions contributes to the person's persuasion that he/she can cause damage to himself/herself by means of the specific (individualized) subjectivism of the social perceptual perception, which becomes deformed due to the defenses to please the idealized Self.

In the depth psychology a special function is given to a dialogue. There are some peculiarities of the dialogue:

It "brightens" the visualized presentment, selected by the person, it contributes to filling it with the emotively unique contents;

It unites and synthesizes the conscious and the unconscious in the person's spontaneous activity due to the questions, which generate an activity impulse;

It is based on the prerogative of the person's "free-going" activity and the dialogical prospect of "following him";

It contributes to accumulation of the behavioral material for his sense correlation and further interpretation which is the catalyst of the diagnostical-correctional process etc.

A question can arise: "And how is it connected with the archaism?", that has been mentioned earlier. Archaism is present everywhere and it is firstly involved with the category "extraexperiential", which is integrated with the person's ontological acquirement, that sets motivation and spontaneous initiative of the behavior.

Cognition of the archaisms is connected with the discovering of the senses, it is important for a psychologist conducting ASPC to be able to read them. Motivational factors are often not only unrealized, but also hard to be understood by a person, but this does not lessen the imperative power of the efficiency manifested in the behavior.

40 -year researches conducted by us in the format of the psychodynamic paradigm let us define that such motivational-archaic factors are first of all the Oedipal dependences, which find their embodiment in the phenomenon of guilt. We have an impression there is a priority of the phenomenon of guilt, which is rooted in the Oedipus complex. Guilt latently inevitably preserves the main stem of the connection with Oedipus, all the other archaisms (sacrifice, slave-submission, tendency to reign) are added to it. The latter distinctly proves the analysis of the masochism phenomenon.

Psychodynamic research does not touch such derivatives of the archaically-motivational formations as general tendency "to power", envy, jealousy, superstitions, fear, aggression, egoeroticism etc. - all this is characteristic for the person's everyday consciousness in its archaic constituent.

Psychodynamic paradigm (with the 40-year genesis) "has not even considered" up to recently, that the category of "masochism" will help to find the answer to the problem of archaisms. To tell the truth, our books put us closer to discovery of this problem, namely: "Tendencies to the Psychological Death", "Self-Deprivation of the Psyche and a Person's Disadaptation", "Aggression" [0] etc.

In other words, there are some bases to state the fact, that a human's psyche has tendencies connected with self-punishment by impoting energy (self-deprivation) and reorientation of the aggression vector to oneself, which causes a tendency to the psychological mortification and feeling of devastation. The tendency to selfimpoting comes into conflict with the necessity of the social self-realization as well as with the life instinct. The latter is represented in the poem by Valentyn Molyako, the academician of the National Academy of the Psychological Sciences of Ukraine:

Everything inside is mortified,

My sorrow has no limits:

I see a body, only a body,

Only a body, and no soul.

And my life is like anatomy,

When vanity eats everything up to the end, 
When they look in a hostile manner-

And you see only bodies.

You will tremble with a cold perspiration,

Which is icy, like an icy shower-

How many people are hopeless around,

They are humans, but with mortified souls.

Who killed them? Were they self-murderers,

Who were dying in lies and feelings?

They had lost themselves and exchanged

At the markets, at work, and pubs.

And very often I feel horror,

When I see no signs of truth.

People run, and cry, and sing,

But it is evident: they are dead.

Our scientific research is connected with the results presentation of the psyche depth cognition empirics. That proves the synthesis of the human acquirement, the responses of which are expressed in the ability of the psyche to reflect itself both in the personal drawings "Tattoo" and "Tattoo of guilt". Originality of the methods is in the propositions to match the author's picture of tattoo and a series of the artistic works reproductions and rank them according to the significance to discover the essence of one and the other tattoos.

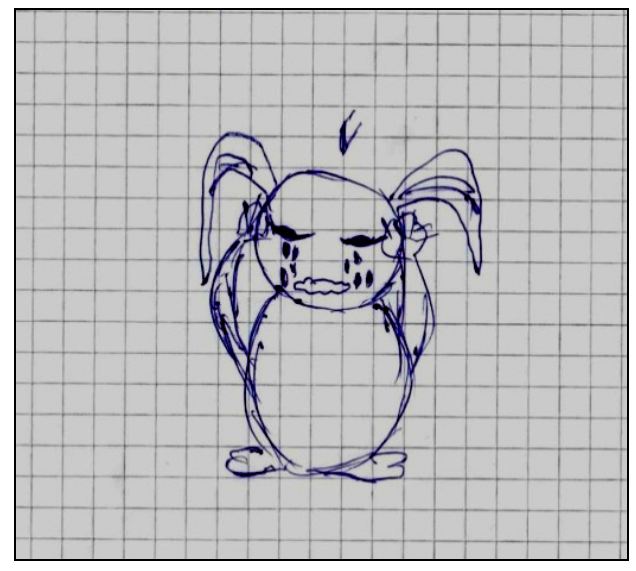

Fig. 1. Tattoo of guil

Here we give a short-hand record of the psychoanalytical session with the student of Cherkasy Institute of the Fire Security named after Chornobyl Heroes. A demonstration session took place (according to the invitation of the institution) in the assembly hall with the visualization of the process. Free will conditions were followed, when the student V. showed her initiative to make the proposed thematical psychological drawings of tattoos.
A short-hand record of the "Personal tattoo" and "Tattoo of guilt" drawings psychoanalysis (done by the respondent $V$.) in the combination of the artistic works reproductions, selected according to the emotive criteria in consistency with every "tattoo" drawing.

Organization of the depth cognition process. One of our tasks was the depth cognition sense of the "personal tattoo" and "tattoo of guilt" drawings (the psychologist tried to autonomize guilt from the respondent: in imagination it was put on a separate chair). The respondent V. was offered: a) to draw two thematical psychological drawings: "Personal tattoo" and "Tattoo of guilt"; b) to find a match from the artistic works reproductions for every drawing of the "Tattoo", which are emotionally consistent with the sense of the tattoo; c) to rank the selected (to "the tattoos") reproductions in the order of their emotive significance.

$V$. is a student of psychology, Cherkasy Institute of the Fire Security named after Chornobyl Heroes (March 2019, a demonstration lesson).

A session anchorman is a psychologist T.Yatsenko-(P.).

P.: What do you want to start with: with "tattoo of guilt" or with "personal tattoo"?

V.: With "tattoo of guilt" (Fig. 1).

P.: What feeling does this tattoo arouse of you?

V.: Negative, very negative.

P.: What presents this negative in the drawing?

V.: This is a hare sitting with the sunk ears, keeping his head and crying. desperate?

P.: Does it mean this hare is perplexed and

V.: Yes, it does. He has an open mouth - he is crying and shouting.

P.: If you saw such a hare, what feelings would you have?

V.: Embarrassment, I would feel sorry for him.

P.: Would you try to help him?

V.: I would, I would ask what had happened. Because this is not a pleasant picture.

P.: Why did you choose an image of a hare? He runs fast, he can care about himself rather well. How did it happen, that suddenly he had got such a trouble?

V.: He has made a wrong decision, he feels guilty ..., now he has the results. He is very upset 
and he repents. He blames the whole world that it has happened to him.

P.: What would you tell him?

V.: "Life is still going, and even if you have made a mistake, next time prevent it".

P.: Have you ever got such a situation?

V.: Yes, of course, I know it.

P.: Has anybody helped you to lessen your great tension? Have you coped with that yourselves?

V.: I have done it myself.

P.: Did you try to find anybody, anybody's help?

V.: In general nothing helped, I did not want anything and that was all... as if it was the end...

P.: Did you feel isolation?

V.: I did. I had some closedness in myself, I looked deep inside at myself.

P.: How long could you be in the state of suffering?

V.: It is still present up to now (as if it has moved to the depth) - it is easier now.

P.: Does it mean it has happened recently?

V.: Yes, it does. The next drawing is "Time" (Fig. 2).

P.: Did it happen that time on the one hand as if had stopped, but on the other hand - this figure wanted to wind it backwards. Did he want, perhaps, to prevent something mentioned above?

V.: Yes, he wants the events that have happened not to return.

P.: What feeling does this drawing arouse (Fig. 2), and where are you? And what are the action prospects for this person?

V.: The feeling is that nothing is going well for this man, who is trying to put time backwards. It is impossible. He understands himself, that no matter how great his desire might be, this is impossible.

P.: But does the person still reproach himself for he has omitted something in time parameters?

V.: Yes, he does.

P.: As ancient Greeks said it was very important to feel "place, extent and moment". If one loses the moment, everything will turn upside down. Have you ever had the feeling, that you have got stuck in such a state and you are moving around "the vicious circle".

V.: Not often, but I have had this feeling. Perhaps, just that dramatic situation gave a push to the desire to put time backwards that is the reason of this drawing selection.

P.: And to put time backwards, in your opinion, is due to the ratio (the hare in the Fig. 1 has a big forehead), due to the rational pondering, or due to "the depth of suffering"?

V.: Due to the depth of suffering.

P.: It is evident that it has happened that feelings has captured you.

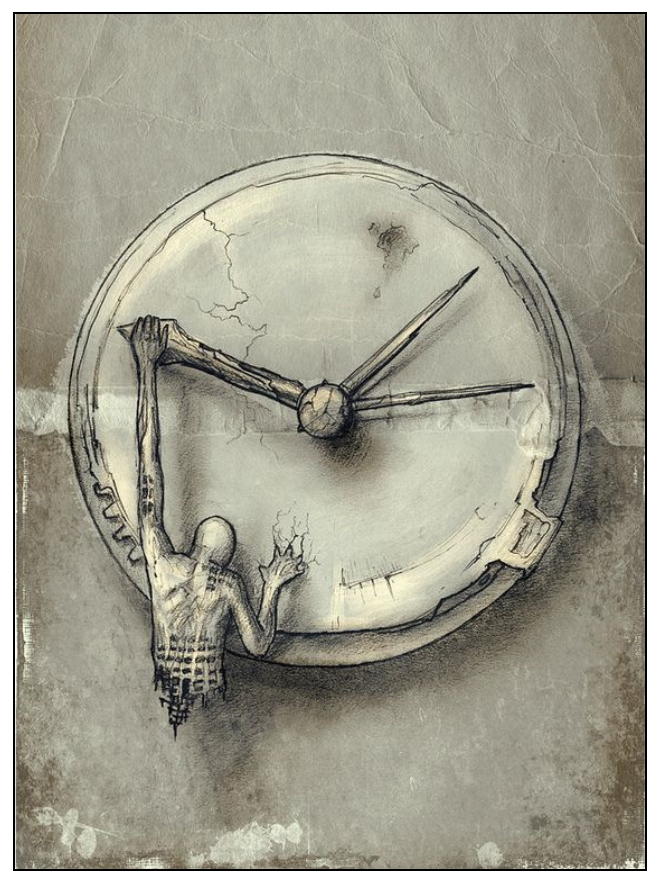

Fig. 2. Author and title are unknown.

The respondent's title is "Time"

V.: Yes, it has. The next drawing (Fig. 3 illustrates this state) - "Sinful Angel" is very distressed.

$\mathrm{P}$. What is this person suffering?

V.: Grief. For me this drawing characterizes falling down, weakness, hopelessness, grief, feeling sorry for something, disappointment because of what has happened.

P.: The thing, that there is really one angel's wing, and the other one is damaged, indicates that something as if has come out of your control. You have not predicted, you have not realized "where it has come from", you could not catch the moment to predict it, and thus you considered yourselves being innocent.

V.: I cannot say I have considered myself completely innocent. I just did not think, it could have such grave consequences. As if my wings were breaking - I sharply felt it.

P.: It means that you have no direct feeling of guilt, but the consequences are distressing you. Because you have omitted something somewhere, so we have such a drawing (Fig. 3). It is not surprising there is that clock (Fig. 2) - as if it stops 
time of the life advance. How long have "this stop" lasted?

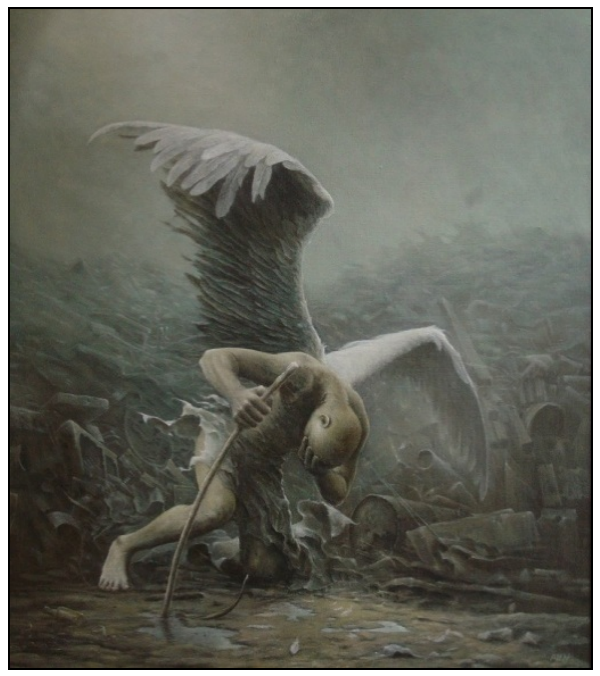

Fig. 3. T. A Kopera, unknown title.

The respondent's title is "Sinful Angel"

V.: Unfortunately, it is still lasting.

P.: It means that you are not free of the situation illustrated by "tattoo of guilt". Have you experienced the similar state, or it is just a metaphoric-symbolic drawing (Fig. 4)?

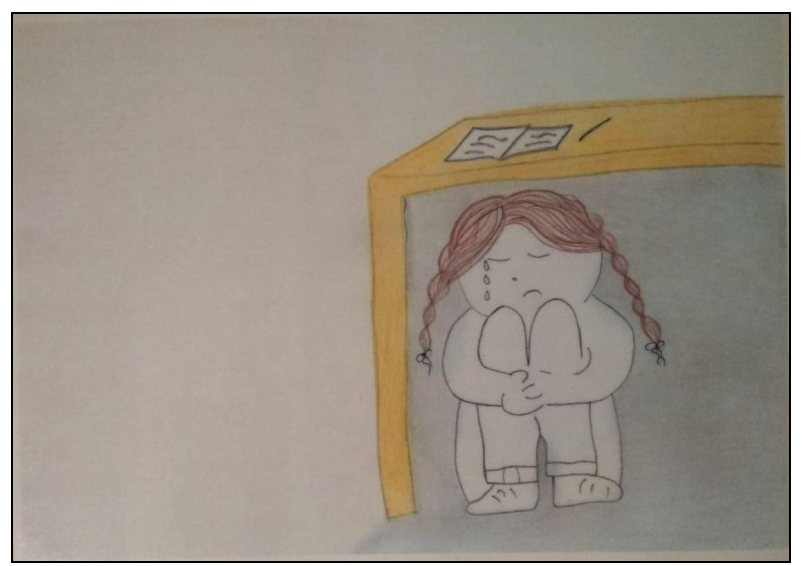

Fig. 4. Psychological drawing, made by other participant of the ASPC group

V.: This drawing resembles "tattoo of guilt": a girl is crying, her eyes are closed - she does not see many things. And this table is as if her shelter, she is not understood or supported by anybody. The girl is alone.

P.: What does this drawing resemble (Fig. 5)?

V.: It resembles Jesus Christ, who has been crucified. Here (Fig. 5) this person blames herself for some sins and internally "crucifies herself".

P.: Was the suffering an internal comfort, as if it (such suffering) excuses you in something and even raises you in your own eyes? Was it as if you were rising to "a pedestal" (Fig. 5)?

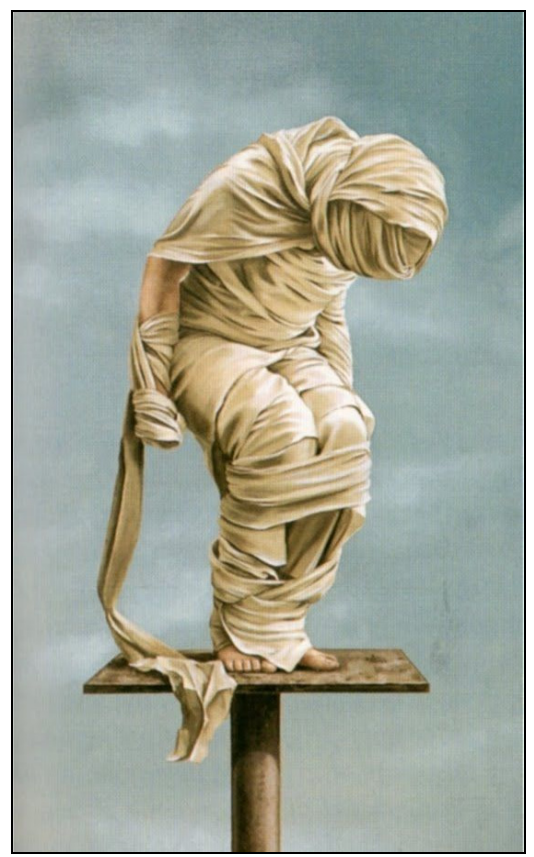

Fig. 5. A. Marcus, unknown title.

The respondent's title: "Self-Crucifixion"

V.: No, it was not. This experience does not decorate me in any way, this is as if a sentence.

P.: What are the differences between this person's feelings (Fig. 5) and the hare's ones (Fig. 1, "tattoo of guilt")?

V.: The hare shows his tears and grief openly, and the person had a closed face for nothing to be seen. This is a concealed internal suffering, and it is the hardest one, this is the feeling of deadlock, and therefore hopelessness, this is pressure that comes from inside.

P.: Here it is the next drawing (Fig. 6). Again we see a human or an angel with the broken wings. She is innocent, evidently pure, without any evil intention, but is she suffering and has no prospects of flying?

V.: It is not that she is pure ... She just has had to put off her angel's wings and now she is crying over them, because she has needed them, and now she cannot use them ... she has had such circumstances.

P.: But is she crying she is sorry she has had to put off her angel's wings? Maybe she has been led to this state? Because she has risen over something using them very high and therefore she has lost something form the life realities - this is my hypothesis. What will you say? 


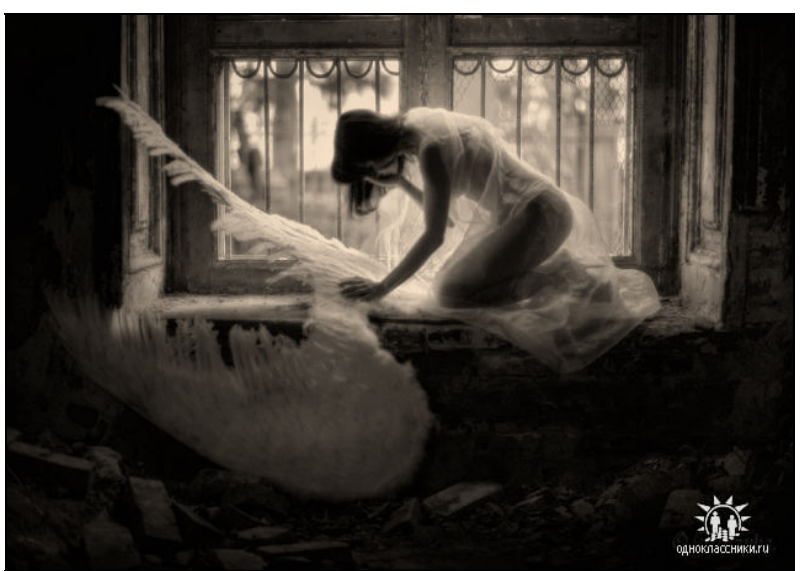

Fig. 6. Author is unknown. Angel with the broken wings

V.: Yes, this is really so! These angel's wings have not very seldom disguised something and provided high rising over other people.

P.: Then the girl, rising over the reality, could not manage the reality of the circumstances that caused disappointment and the state of suffering?

V.: She did not subdue her ambitious needs. She could not block or neutralize them. "If you give your heart freedom - it will lead you in slavery". She has allowed herself to have such freedom, flew to the wrong place, owing to the wings, and as a result - we have what we have ...

P.: Is this person (Fig. 7) your image?

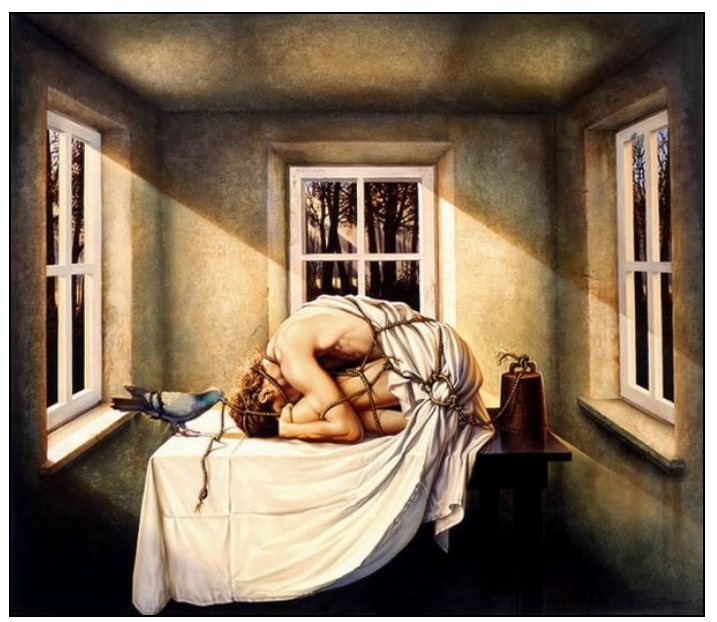

Fig. 7. Z. Zademack. Small assistant

V.: Yes, it is me. Here guilt is connected with the burden, which pulls down (to the right on the table), and a bird is my friend who has anyway supported me and she wants to pull me out of this state, but at this background she is only a bird, i.e. she has no power!

P.: She has no power as compared with the hardness of the state felt by this person. If we consider a bird as a symbol of nature, we will see that nature is wiser than any human problems. Did you have the situation that your friend tried to give you support? Or had she no power at all?

V.: Yes, she tried. At first she did not support me at all, but later she changed her mind and decided to support, but for me that support was too small and unnoticeable. I wanted bigger support and according to other parameters, in other place and in other direction.

P.: Was it possible, that your friend was glad that you had burnt your wings? Was it because she could not fly so high herself, as you managed to do? Did it happen, she might envy that you were a beauty and had such "flights"?

V.: Maybe, I am not sure.

P.: Where do you feel in this drawing (Fig. 8)?

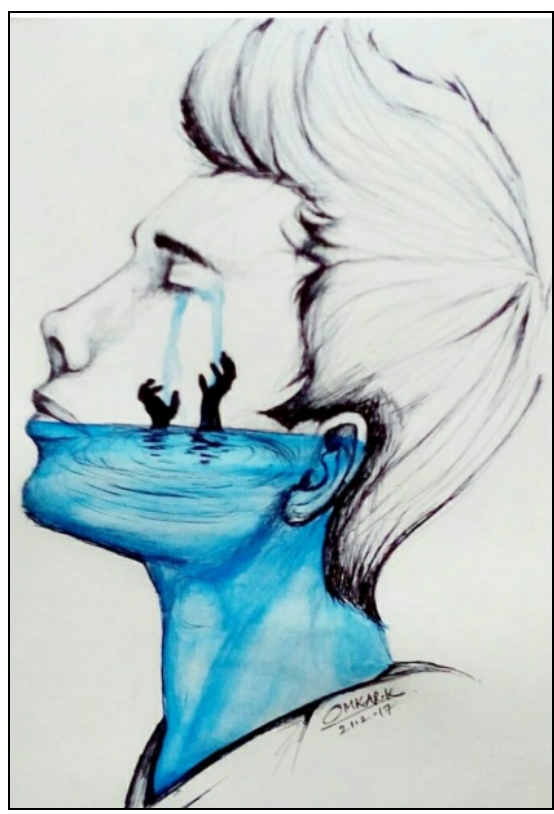

Fig. 8. O. Hochare, unknown title

P.: It is very interesting: you are drowning in yourselves and in your own tears. Now you understand it, and it will not be so traumatic for you, and it will be familiar, rationalized. Due to this understanding there will be less "self-damage", you will bring destructive energy out through ratio and waken your own self-preservation. Now we have this drawing (Fig. 9). As we see the figure is pulling some burden - evidently, it is some experienced life troubles, fixed in the energetically saturated traces (fixations). The burden on a rope is archetypically the symbol of a navel-cord. Is this situation connected with the blood relatives?

$\mathrm{V} .:$ No, it is not. This is my personal intimate experience. 
P.: If so, there may be some transfers from your relatives, i.e. from your primary libido objects. For example you dated with somebody who resembled your father, your brother or somebody else psychically significant.

V.: He does not resemble anybody of my relatives, but my "first love".

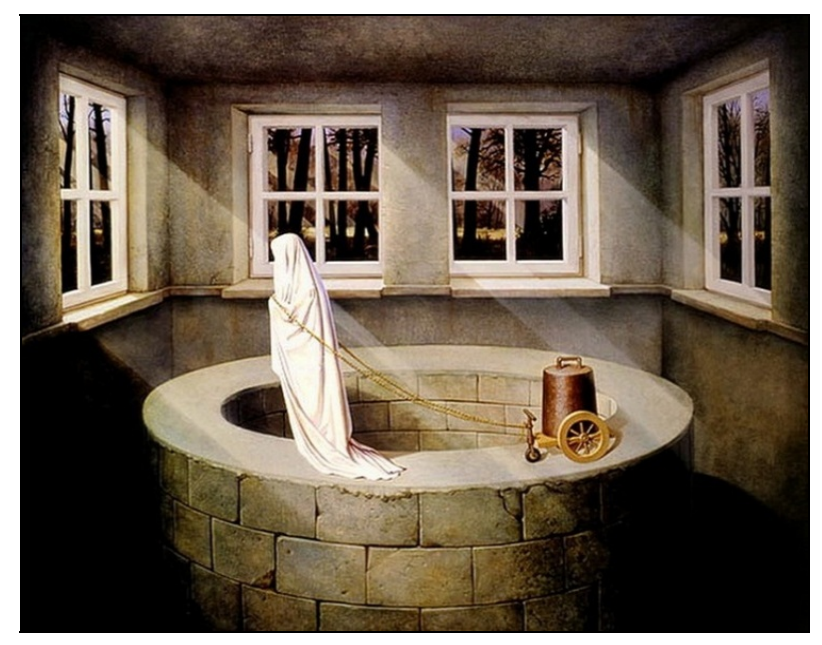

Fig. 9. S. Zademack. Kreisläufer (Circle Runner)

V.: Inside, these are my hands out of water. It seems I am drowning in my tears, in my grief (it is all Self).

P.: Yes, if it had been emotionally strong, it made a fixed center which stimulates the desire to find a substitution for him. And some period you thought that you had really found one. And you believed. It seemed you "were flying" as "a light angel"?

V.: Yes, that was true. In general, this drawing for me resembles the person, who is standing over the abyss and wants to make a suicide.

P.: Did you have such thoughts or only feelings that life was coming to an end?

V.: It was not just thoughts. There were even attempts of a suicide, but it turned out to be not so easy. Later, when I found some information (about that person), I understood it was fool from my side (I could become an invalid). And I am sorry about it and, thanks God, that everything has turned well. I am well and I am sitting here and working.

P.: It is good you have come to this demonstration lesson, and now you will trace the similar destructive tendencies and will be in greater safety. It is so interesting what we have just talked about. The next drawing (Fig. 10) illustrates something similar. It goes about love, which evidently has taken place. But, since the girl is bound by the chains ("navel-cords"), then does this problem not set you free?! These are some remaining chains from the experienced trauma. When you already know it you can smile (and not to fall in such suffering). Well, it is good you have had your first love, and it has brought you some experience, but further live a free person. You have experienced so much up to now!

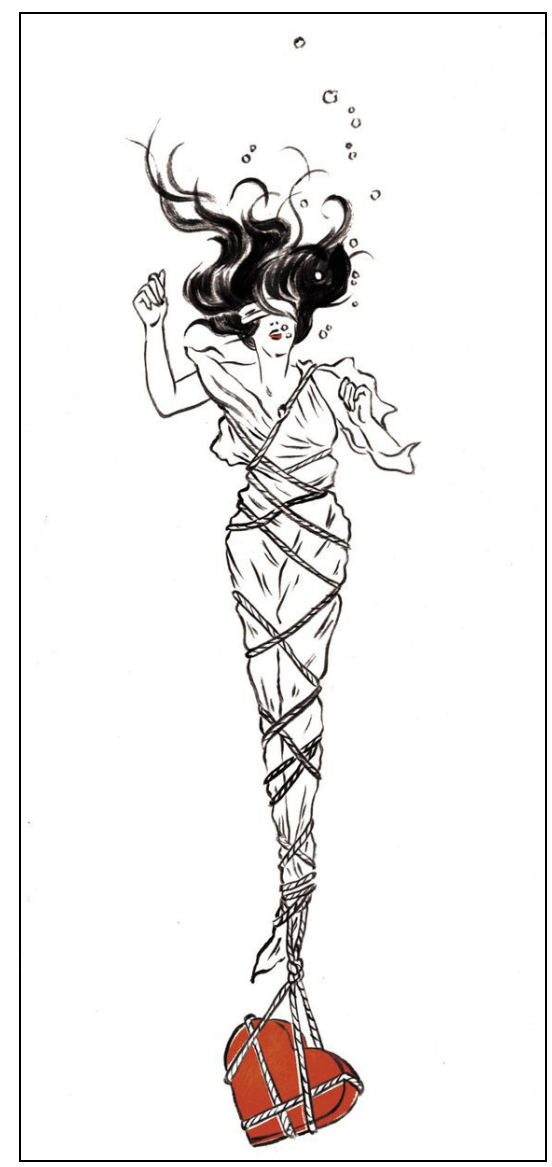

Fig. 10. K. So, unknown title

V.: Though the guy looks like my first love ... I am with him up to present. After all I have experienced I will appreciate it more. But I have a feeling of guilt before him. And simultaneously, I have a grievance on him for his actions and all this together. It is all mixed in me and keeps sitting. To tell you the truth, it is not so stressful as it has been at first. It is coming away little by little, but still it can return and capture me.

P.: Cannot you discuss with this guy the problems we are talking about?

V.: We agreed not to discuss this because this causes a quarrel.

P.: Does this mean you keep dating but live with the "frozen" wound, which you have experienced?

V.: Yes, that is true, and to touch it is undesirable.

P.: Who caused this wound? 
V.: I did it myself. And later he added to it by his behavior.

P.: It is necessary to understand that nobody in the world can hurt us so much as we can do ourselves. It is because we are the closest to ourselves. There is also a power of projection when guilt is thrown [projected] to the other person.

V.: It is not that I wanted to throw this guilt to somebody, but there was a situation when I wanted to think it was not my fault ...

P.: To think who is guilty, either you or he means to walk around "the vicious circle". The most important thing is to informationally read the situations in which you happen to be for preventing them. The next drawing (Fig. 11) proves the availability of your tendency "to return to your mother's bosom". And then there is a need of selfbirth, which gives a feeling of power: "I could do self-establishment". But the burden of the problems causes the tendency "to psychological death", that is why your today's psychoanalysis is so important. The next drawing (Fig. 12) shows, that you have not rationally strengthened yourselves for your steps in the future to be free from a speck of risk. It is because the girl is standing on the cornice, from which a rope is hanging (a raven is sitting on it), one can step on it. That means there is a risk you will not have the grounds for self-preservation.

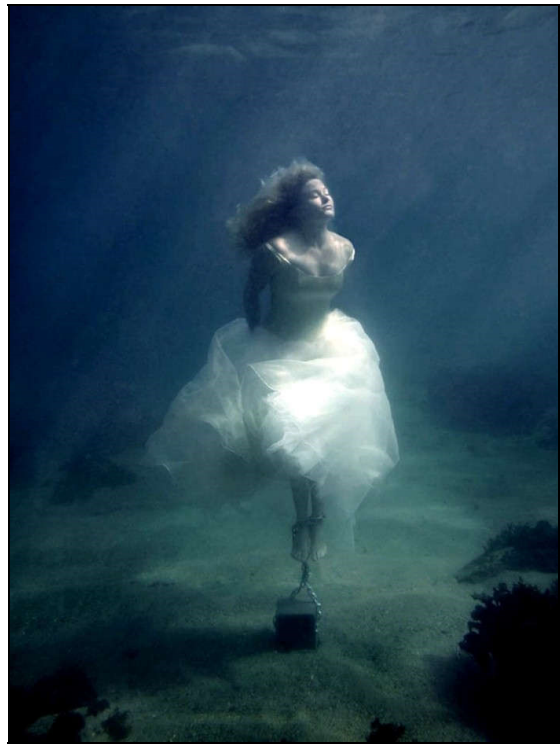

Fig. 11. Photo M. Mawson from the series "Under the Water"

V.: Does that mean that I am ready to die only not to make the same mistake?

P.: It is possible to realize and understand that we live only once and the fact that you fell into the tendency hands being between life and death should be a difficult but reliable lesson for you. It should prevent you from making wrong decisions and hasty steps. You need to keep the fact of your selfconquest. Of these two tattoos, you have chosen, first of all, the "tattoo of guilt". You feel that you are a central link of it. You feel guilty, first of all, about yourself.

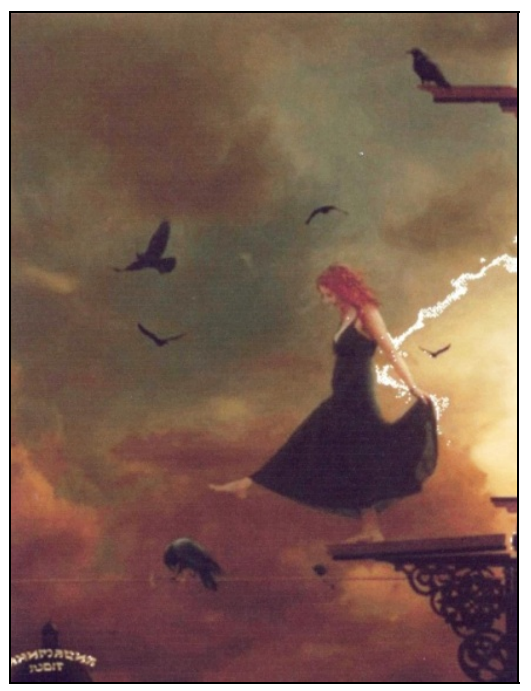

Fig. 12. Author and title are unknown

V.: Yes, I understood this during our work. Now let us consider "personal tattoo" (Fig. 13). This is a snake, Gorgon. Cobra, it has some little snakes out of its head.

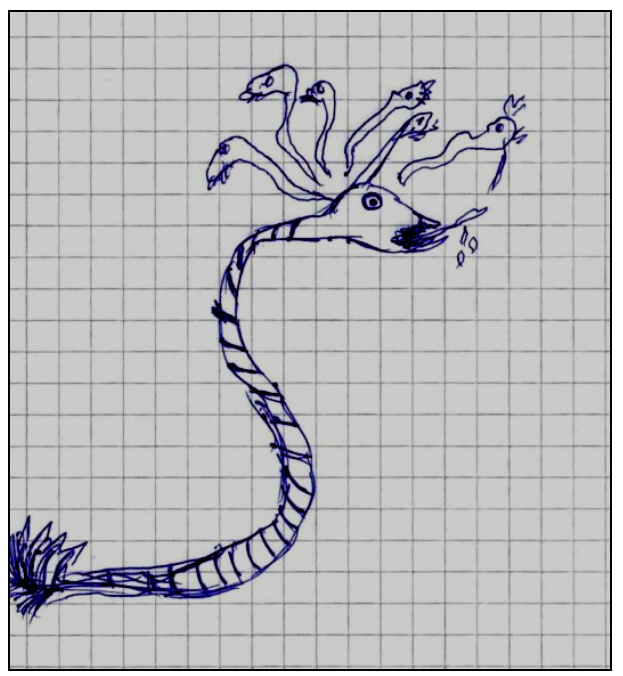

Fig. 13 Personal Tattoo

P.: The snake's symbol has a "mortido" (destructive) meaning: the intelligent, but, is directed either to revenge, or to be burdened with its self-recrimination. Why does it have such an unnatural tail?

V: It's like a club, a switch with steel thorns, it is capable of striking someone. It can hit at someone. 
P.: So, would you like to revenge?

$\mathrm{V}$ : Not exactly (I needed to protect myself, perhaps, from myself), but I wanted revenge as well.

P.: Where would you get this tattoo?

V: On the hip or on my belly.

P.: Do you want the other people to be afraid of you?

V: Yes. I want to be stronger, that's right. I do want people to be afraid of me.

P.: So, there is an illusion: "when I am evil, I am strong and secure." But in reality, the greatest force is not in the "darkness", but in the "sun".

There is no life without the sun. That is, life is in the energy of a libido, which is needed for yourself and for others. Just imagine how you would scare the boy if he saw this snake on your body. In the following drawing (Fig. 14) there is a girl who cut her wing. How do you understand this picture?

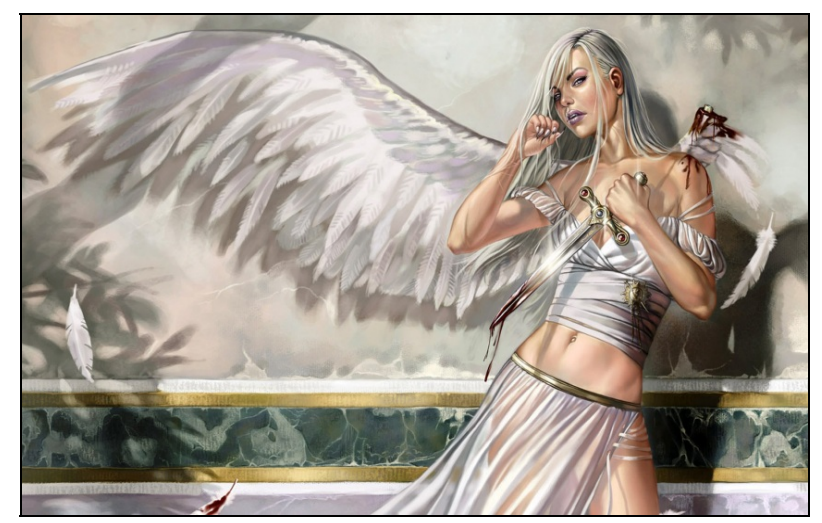

Fig. 14. Unknown author. Angel

V: I feel as if I am cutting off my wings, one of them has been already cut. It happened due to my imbalance and aggression. It is finished in picture 6

P.: So, you confirm the hypothesis that a person is more harmful to himself or herself than anyone else. There were similar drawings: Fig. 3 and Fig. 6. It turns out that we accuse others of our own failures and do not notice how we injure ourselves. And it breaks us down. Strength is inside of us and in our knowledge of what is happening to us. We must follow the way of consciousness, but not suffering. Everything that happened in life stipulates the fixation of the mortido energy. The logic is the following: "If I can do this to myself, then others must be feared of me." Tell us what you see in this picture (Fig. 15).

V: I feel both a demon of anger, and a helpless angel. Everything depicted in the picture I have inside. In some circumstances I hesitate and the demon wins. And on the contrary, I remain an angel when I have to be tougher, and this is my vulnerability. Therefore, obviously, a girl in white has only one wing fully functional.

P.: Do you feel a certain dissonance of behavior - "out of place"?

$\mathrm{V}$ : Yes. Where it is necessary to be tougher, the white angel appears, and vice a versa, something demonic, black appears when I must be tender.

P.: Perhaps you are afraid that you cannot overcome the cruelty of the opposite side. Therefore you are adjusting so that not to suffer from the force that is "on the other side" of yourself.

V.: It's really so, I knuckle under.

P.: How often do you feel these images inside of you? Do you feel that you are their carrier? Is it your essence?

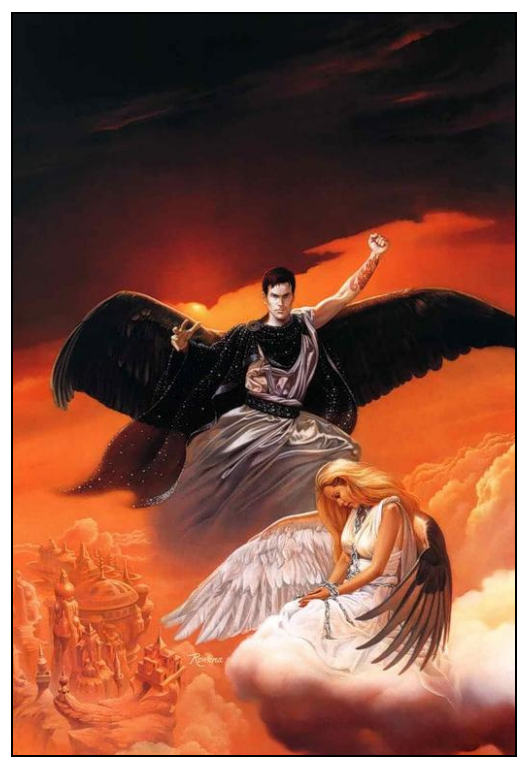

Fig. 15. R. Morrill. War in Paradise.

V: No, they are sitting separately; I do not feel them together (either ..., or ...).

P.: "Either ..., or ..."? Are you an angel or devil?

$\mathrm{V}$ : They are together, this is so, but they appear separately. I can say for sure that they don't exist in their pure form: I can be purely neither a light angel, nor dark devil.

P.: How are you represented in your family?

Q: In my family? I am the devil, definitely.

P.: Who feels it? Is it your mother, father or anyone else?

V.: I think, both mom and dad. I am the devil with them. And other relatives see me as an angel.

P.: So, do your family members see you as the devil? 
V: Yes.

P.: So, are you protesting against something? Is there anything unacceptable?

V.: Yes, there is something that is unacceptable for everyone.

P.: When did you start to feel it?

A: Approximately when I was 15 .

P.: Was there a certain event or the reason that you suddenly felt so?

V: No. My mother was not involved in my upbringing when I was a child. Usually, my aunt, grandmother, our neighbor, or someone else spent time with me.

And when I was 15, my mother changed her job, became closer to me and started to parent me in her own way. I got used to a gentle treatment, but she took an authoritarian position and didn't care about my desires. My mother began to impose such upbringing as she had been brought up.

For me it was unacceptable. And it is still unacceptable.

P.: Can you admit that you have had such experience with a "mother-black devil" since childhood?

$\mathrm{V}$ : Yes. She sees me as the devil, and I see her as the devil as well. That's the "vicious circle".

P.: It turns out that you did not like the devil's nature of your mother. Did you, in order to withstand, form the devil inside?

V.: Yes, that's right.

P.: Then you pay dear for your mom's tactlessness. You pay dear for your childhood as well.

V. I understand, I can't but continue doing it. It goes without saying.

P.: So, it means that your mother is very important for you, if you let yourself to be wasted. Being the devil, you become identical with her.

V.: Yes, it's true but sad...

P.: You are wasting yourself. The beautiful image of a gentle lady (woman) is being disappeared! Your mum seems to tie your hands, and then you obviously do not do anything, you are not active.

V.: I do not like to be told what to do. I understand that mom is trying to do her best, but I want to choose what to do myself. I am often deprived the right to choose. They all decide for me because they think they know better and want better for me, but I want to choose myself. Even if it is wrong, I will realize my mistake and fix it. I will do it properly. I am not going to admit the advice like: "do what we say or..."

P.: Do your parents think they are not blessed with their daughter?

V.: Yes, I feel it though I am ashamed of it.

P.: Do you have the same thoughts concerning (mutually) your mother (or your father)?

$\mathrm{V}$ : Sometimes I think that I was not blessed with my mother. But then this thought disappears and I continue thinking that she is a good person and I love her, despite of our quarrels.

P: So, are you constantly transferring into a light figure (Fig. 15)?

$\mathrm{V}$ : Yes, I am.

P.: Are you transferring into a light figure more than your mom?

V: I do not know. My mom also loves me and shows it.

P: So, both of you love each other. Is there anything dark in your relationships?

$\mathrm{V}$.: Yes, and it is constant like fate.

P.: Now we are talking only about mother, although you said that your mother and your dad were on the same level. Is your mother more significant for you?

V: Dad supported me, even when my mother was not right. But then they began to quarrel. My dad supported me, my mother shouted at him, and, as a result, I decided not to quarrel with my mother, because he often took her side.

P.: Could feel that your daddy betrayed you?

V.: Sometimes I felt lonely in my family. When I realized that my parents could divorce, I made up my mind to it. I didn't want them to divorce.

P.: Perhaps you have instigated your mother's attacks to make sure your father protected you in order to prove his love. Did you hope for that?

V: I hoped he would support me, because I felt lonely and suppressed.

P.: For you "love" means "support". Speaking about your personal relationship, was there anything like that in your relationship? Why did you behave so severely? Did you expect support and complacency from your partner?

V: No. My boyfriend always supported me. There was something different.

P.: So, what's the problem?

$\mathrm{V}$ : Because of his mistakes. In his company I am always a "white angel". I am not the devil, even if I do not like something, I save my face. 
P.: If you are an angel, then why have you caused such a dramatic situation, which we discussed before?

V: When I am with him, I am an angel, but my hands are tied (as in Fig. 15), and when we are not together, I become the devil with knives. I am very evil devil. When I am aggressive (in the presence of my boyfriend), I am trying not to show it and keep calm ("I tie my hands"). Because I'm afraid, he may not like it.

P.: You are wasting so much energy to control it! Do you have to control and restrain yourself constantly in anything, even to mortify?

$\mathrm{V}$ : Yes, I do. And even if my mother is not right, I try to restrain myself in my relations with her.

P: It's hard, a lot of energy is being wasted ineffectively, because you feel that you're losing yourself. As if you are not yourself.

$\mathrm{V}$ : I do not know what it will result in but I have to mortify my emotions, and it's difficult.

P.: Maybe, you will be a good actress in the future. But the question remains: why is a bunny in tears ("tattoo of guilt", Fig. 1)? If you can fix situations so why .are you in feeling all this?

V.: (Fig. 1) I am depicted in that picture when I was making certain mistakes.

P.: So, did you feel like that?

V.: Yes, I did. I felt it, I know what it means.

P.: Let us consider the following picture (Fig. 16). Such a beauty is looking into the mirror and sees something mortified. You're losing yourself. If you suppress your emotions and mortify the "black devil", it turns out that "you are not yourself". It means mortification! Then you feel that your mother, who does not accept you as you are, instigates you to mortify something in yourself. Of course, it will never come to your mother's mind, she believes she is making your behavior correct in order to make your life easier, she also does not have any idea about mortification.

$\mathrm{V}$ : Her position is the following: "Let my daughter be a little girl and live with me comfortably. I don't want her to think herself, make decisions and be brilliant." She wants to prevent me from making mistakes. But I want to analyze what I do and how do I do it myself. Even if I do something wrong, I want to analyze it myself in order not to do it in the future. I do not want to be taught.

P.: What drew your attention to this picture (Fig. 16)? And what is represented here?
$\mathrm{V}$ : As if I am looking in the mirror and do not recognize myself: "is it me or not me." As if an angel is looking and sees the devil.

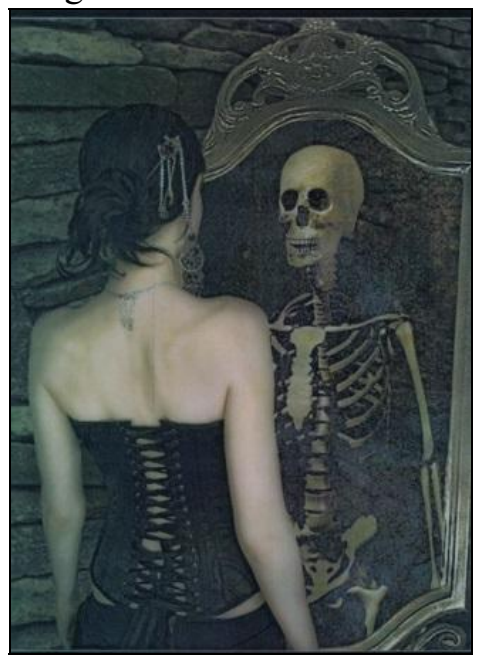

Fig. 16. S. Jersey Mirror of Self

P: You really wish there were no "black" devil (skeleton). You want, but you cannot, because it turns out to be "very much alive." Indeed (Fig. 16) you feel that if you are the devil (aggression, tension, and strength), he will either revive [the skeleton], or you will be stronger.

$\mathrm{V}$ : Let us consider picture 17.

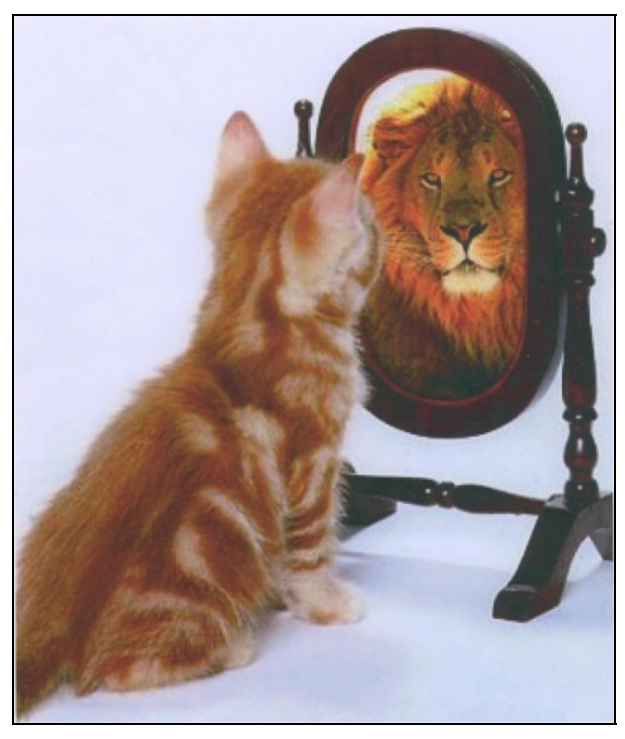

Fig. 17. Unknown author. The Cat in the Mirror

P.: Looking at the cat, we see that you are still a little and tender. It seems that there was a lack of care and love. Perhaps you spent your early childhood with your grandparents or other relatives, and now you want to feel like a cat by your mom (Fig. 17). But when you are such a cat, your mother can turn into a lion and "show" how it should be. That is already known to you. This "lack of 
attention" generates the unsatisfied potential of the child, which would be nice to fill, but, obviously, it does not work out.

Your mom awakens this devil in you, but you neither want to be the devil nor can freeze in a kitten. As a result you become a skeleton (Fig. 16), mortifying yourself through the actualization of the mortido energy. Now you will understand that if you mortify something in yourself, it will deprive you from the opportunity to become such a lion. This "skeleton" (Fig. 16) cannot become a "lion". We must think much our potential and harmonize through its optimal implementation.

$\mathrm{V}$ : While listening to you, I have realized much more, and understood how I complicate everything. Let us consider the following drawing (Fig. 18).

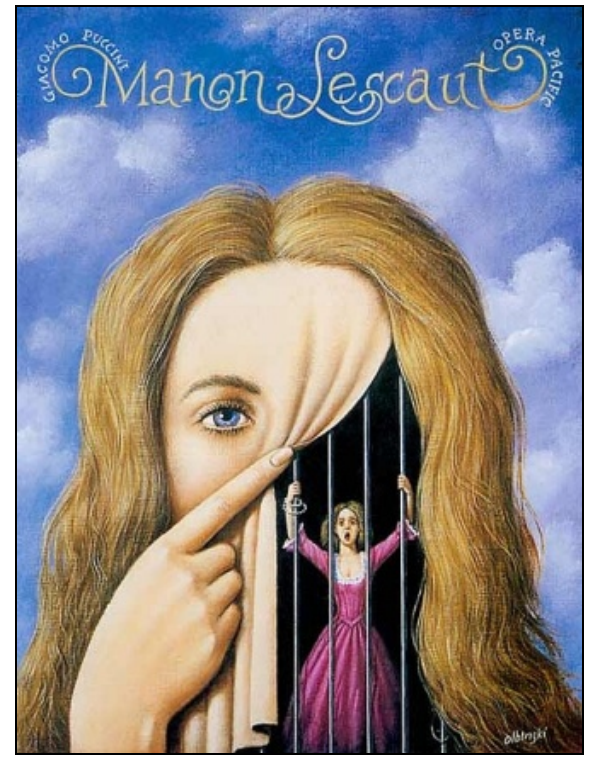

Fig. 18. R. Olbinski.Opera poster

\section{G. Puccini «Manon Lescaut»}

P.: It is very interesting; I have just said that you have something like "the lack of attention", something that your mother didn't give to you in your childhood. Indeed, all the problems with your mother are due to your having been in the child's image so far. You are like being in your mother's womb. And it turns out to be a delay in development. You feel like "a kitten" (Fig. 17). But you are an adult and a beautiful lady. You don't want to be "a kitten", do you!?It is clear that you are looking for strength in the devil, in mortido, in that snake ("personal tattoo"). You see your mom as in the tattoo (Fig. 13). You depicted it as many small snakes being climbed one after another like thoughts. It means that "your mother and your Self are the complete whole". But to depict a mother as a snake means to be blamed, because "all of us have to treat our mothers well." By this (through a personal tattoo), a negative attitude towards the mother is masked and removed, when (in depth) you are inseparable with her: "I am inside of her, I am her essence." Being behind the bars (Fig. 18) indicates a delay in development, in the progress of socialization and the professional success according to your potential. That's why you often need your own experience. You feel that there is a certain delay in your own development. And then you behave as a rioter. Obviously, your mom realizes it (your being not adapted) and therefore is afraid of you. A "vicious circle" is generated. You are standing at a certain crossroads (Fig. 19). You wish your parents had been together, perhaps, to not be involved in.

V: I wish I had not caused it. I wish it had not happened at all.

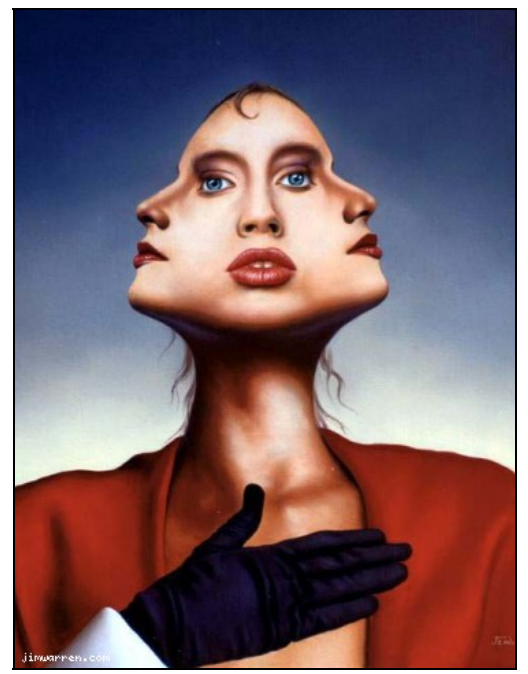

Fig. 19. J. Warren. Welcome to

\section{America}

P: So you want to reconcile something irreconcilable in yourself, you want to make a single (holistic) image of yourself. What did you see in picture 19 when you chose it? What does it symbolize?

V. This drawing illustrates my confusion. I do not know where to turn my head, as if my face is looking around.

P.: Like in a fairy tale: at a crossroads of three roads. That is, a person cannot identify himself?

V: Not exactly. Sometimes I feel that I do not know what to do, I feel confused. Something is tearing me apart, and I am shocked. It seems to me that I am disappearing as if I don't exist.

P.: Participation in psychological correctional groups contributes to the development of the social- 
perceptual intelligence. And here (Fig. 19) the intelligence (forehead) has been brought to nothing, but the soul is suffering. The black glove is pointing to it. Is this black hand yours or anybody else's one??

V.: It is mine. It indicates the "darkness of my soul".

P.: So, there is a problem you are experiencing, but it's difficult for you to solve it. You want to solve it, but you are constantly being trapped in certain internal tendencies and resistance. You are still being closed and isolated, you cannot overcome the "bars" (Fig. 18) to get into the society. In order to do this you need to be free now. The next picture (Fig. 20) points out that you should find the balance of white and dark inside of yourself. Look at this picture, where are you? Are you down the line, in the light, or in the dark?

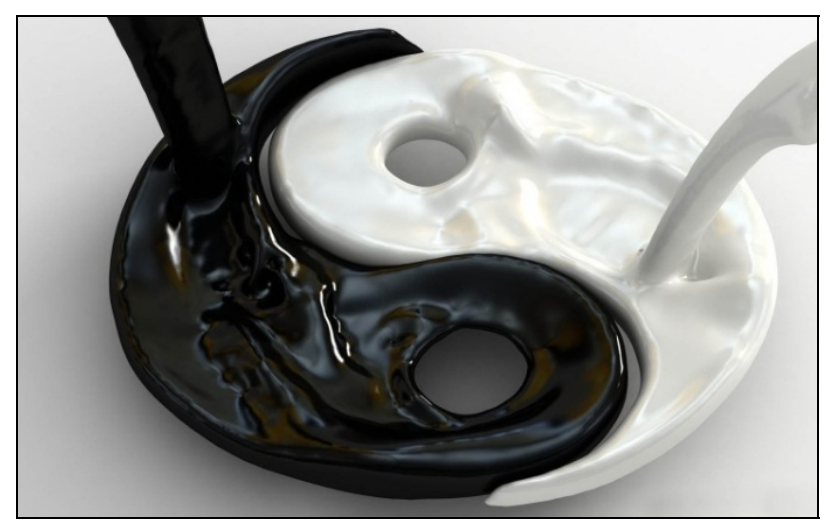

Fig. 20. The author is unknown. Yin yang

$\mathrm{V}$ : In the middle (down the line), where they merge, I am the line between...

P.: It turns out that you cannot identify yourself, because you are the line between white and black. Fixation on parents is blocking your personal development. Being only a border line, you are neither "here" nor "there" (let us remind figure 15): between a black and a white angel.

V.: Yes, it's true. Picture 21 has shown already that I am in the middle and synthesize both parts.

P.: Are you on the border or in the middle again?

V.: Yes, I am a mixture of these two (as in Fig. 20). My father is a light part, my mother is a dark one.

P.: Now we are following the tendency of your fixation on your parents. You are trying to get something independent (autonomous), but it is, basically, only a mixture of one with the other. Your father gets into the light part, and your mother into the dark one. And since the child has been inseparable with them, it turns out that this inseparability forms the bars (Fig. 18).The captivity behind these bars has been caused by the fixation on your parents, especially, on your mother. You argue that the skeleton is vitalizing "mortido" energy. You have to work out the material in order to identify your behavior. You have to identify what part is speaking and what part you would like to say goodbye. Your personal development as an adult has been in danger, especially intimate relationships improvement. You may be both "white angel" and "black one". You cannot realize your potential down the "golden mean" line, therefore: "either ..., or ..." leads to self-mortification: picture 22 is similar to picture16. It seems you're sacrificing yourself due to the unrealized love for both parents. What does this drawing (Fig. 22) allow you to tell?

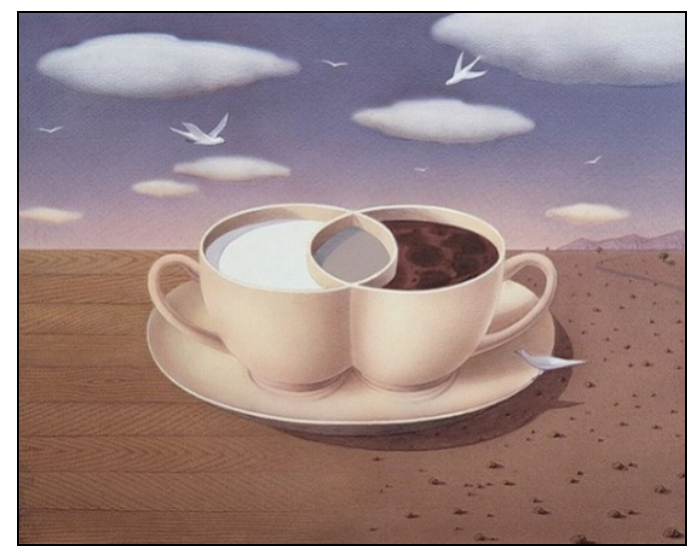

Fig. 21. G. D. Eksioglu. Coffee with Milk

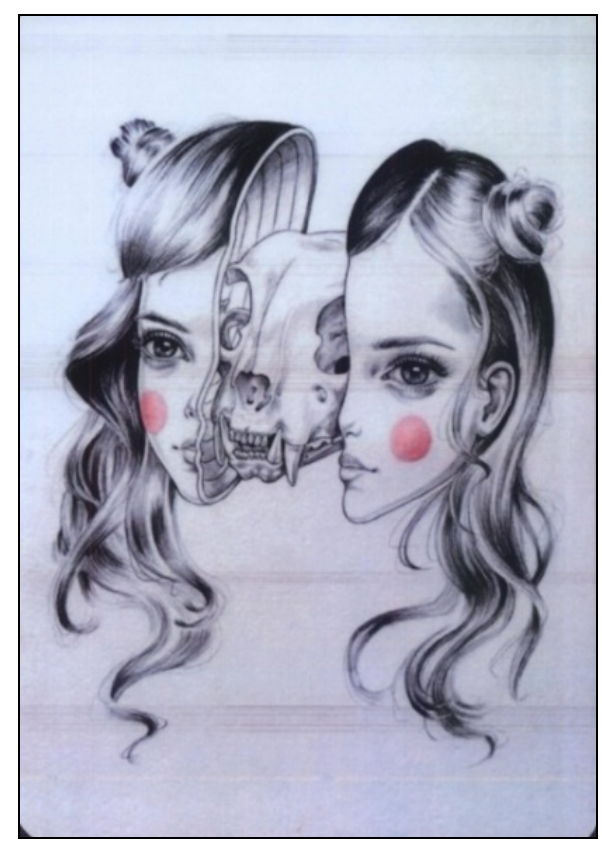

Fig. 22. Y. Philipenko. Cat ladies don't Cry. 
$\mathrm{V}$ : This picture shows that I seem to be good, but everything has been already mortified inside of me, as if I was not alive. I need this kindness for survival. It was a feeling as if I were not alive. Now it's clear that I am mortifying my dissatisfaction and aggression.

P.: Did you have to mortify it in order to be in harmony with your mother and father?

V.: Yes, I did, but there were many other situations with other people in my in life. I suppressed myself through the mortido revival and as a result, I felt exhausted and devastated, as if I was already dead. The site of fire was being replaced by ash.

P.: So, does it mean that many situations in your life awakened a fatal (destructive) energy but you suppressed it (mortified) ?!

V. This "devil of destruction" appeared to protect me and to show strength, that I cannot only be an "offended bunny" (Fig. 1), but also I can frighten another (or others). (I have an insight: this mortification has been caused by the reluctance to be a fearful bunny). That's why the snake spews venom in various ways (see "personal tattoo", Fig. 13) and therefore has a lot of small snakes on its head. It looks terribly, but not surprisingly, this is the revival process. In order not to be mortified inside, the snake has to start acting, otherwise I'm fated (Fig. 22). Snake comes from the skull!

P.: Do you think you scared your boyfriend with your behavior? And does he have any ideas about your internal conflicts?

$\mathrm{V}$ : He said that I could be quite different sometimes. He sometimes does not recognize me. As if it's not me.

P.: Would like to be positive and good?

V: No, it is not necessary to be always good, sometimes you have to "fight back" and to be cruel in order to remain yourself at the same time.

P.: Childhood problems are being manifested in relationships. A corrected person is always free from internal conflicts, having mostly positive relationships. The next drawing you have chosen (Fig. 23) indicates (according to the archetype) the non-birth. If a person has not been not born, it means, he or she is dead. There is no realization of your own potential in some cases. Mortification is connected with that fact that your potential has not been born. It is clear why you are aggressive with regard to your revival. By mortido force you seem to break the shell of your self-restraint. It means that you are interfering with realization of your own potential, both in intimate relationships and in the professional self-realization. Now you get convinced that in certain situations you have to get the ability to remain calm. If you keep calm, your mind will be strengthened so that you find the best ways to harmonize your relationships. You have chosen this picture (from numerous reproductions). What does it symbolize for you? What does it depict?

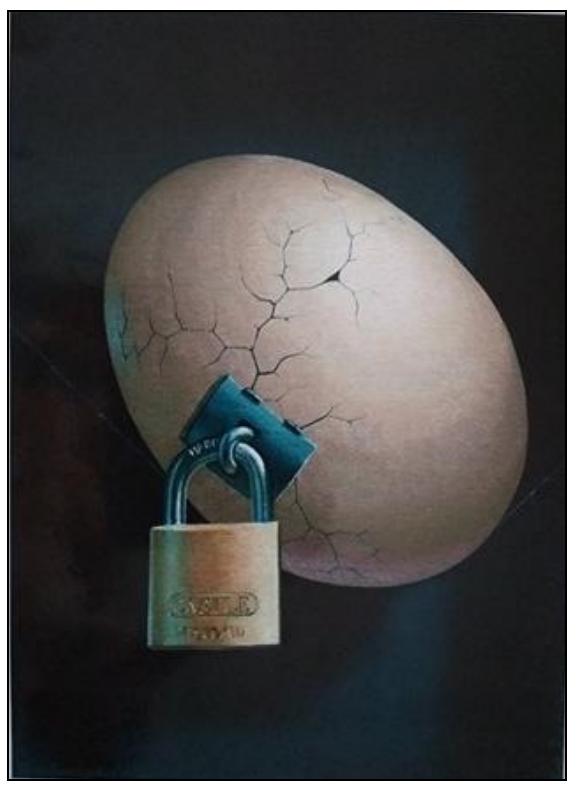

Fig. 23. The unknown author and title.

$\mathrm{V}$ : As though I'm sitting inside and want to escape, because the shell is cracked. But a heavy lock does not allow me to do it. It does not allow me to get free. That is, I'm locked inside of myself, I want to get out, but something is preventing me from doing it. Indeed there is a feeling of the need for a self-birth! As if for a long time I have been harassed by my mother.

P.: Have you created this lock? The law is the following: everything that is sitting in an egg will spontaneously come up, there is much space to come up and step out. But in order to be protected, the psyche is trying to dig into a "uterine" state (Fig. 8, Fig. 11, Fig. 18, and now Fig. 23). It is high time to "be born", but there is some delay. Being an adult "you are still in your mother's womb". And you feel guilty. You can make an effort and be born yourself. Why have you chosen picture 24?

V.: This is me. I am balancing between emotions and mind. Sometimes I ruin everything with my emotions, but then I realize that I shouldn't do it. Or vice versa: I thought I had acted correctly, but then realized that at that moment $\mathrm{I}$ had to focus on 
emotion, not on the mind. I am constantly balancing and, as a rule, it's a "miss" again!

P.: Is there no "golden mean" in behavior? Emotions do not work for the mind and vice versa, there is no balance and synthesis, there is no "golden mean". The tattoo on the man's back may mean that your father is the ideal of your psychological development in life.

V.: Yes, he is more cool-headed. I would like to get this trait and he approves it.

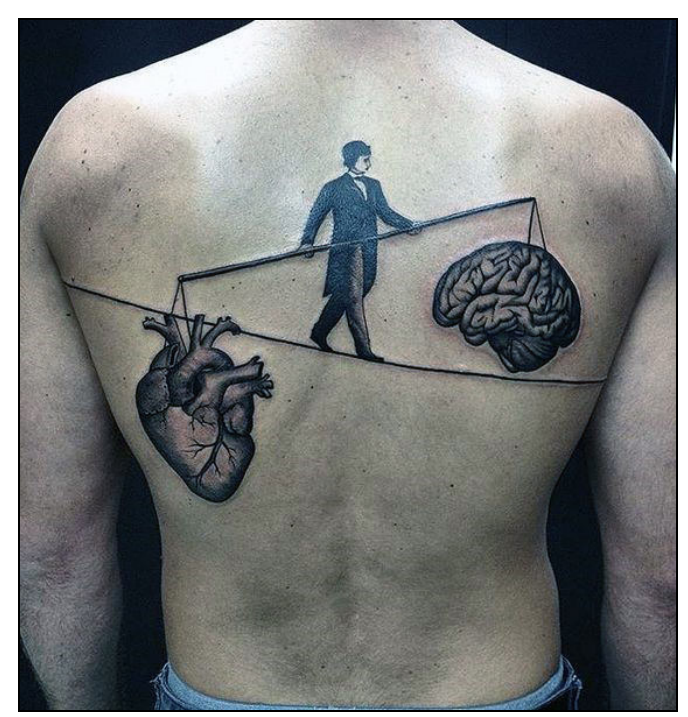

Fig. 24. Unknown author. Tattoo «Weighing Mind and Heart»

P.: Obviously, picture 25 symbolizes what you are afraid of, in order not to be so helpless, insignificant and thrown away.

V.: Yes, it really is very undesirable for me. I felt it in my relationship with my mother more than once.

P.: Did you experience such feelings in society?

V.: Yes, I did. It was quite unpleasant and certain situations injured me. I do not take it hard, because there are more serious problems in my life. I just put it into my pipe and smoked that I should avoid "such hands". I do not want to deal with such people at all. Communication with them leads to the condition depicted in picture. 26. I am sitting inside and hiding, I don't leave my home.

P.: But the man depicted beside looks like a little devil with horns and hooves. That is, you are provoking such "gestures" as in picture 25 .

V: No, I am not. Such behavior helps me to feel strong, but against this background I am just a little devil.

P.: So, due to your desire to be strong you got into hot water. And after the situation depicted in picture 25 some reflection appeared. In picture 26 an adult is thinking: "Why is it so?" And the crooked little child, once again hints at the mother's womb return tendency (inside the head).

V: At first, I wanted to refer this picture to guilt because of thoughts that arise under its influence.

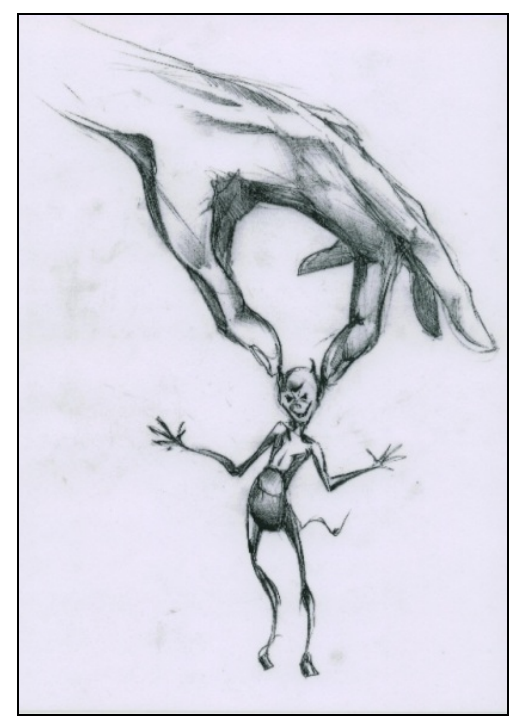

Fig. 25. The drawing made by ASPC group participant.

P.: During the analysis, I was choosing the other drawings, previously related and classified as referred to guilt. It turned out that everything is interdependent!

V: A teddy bear, a child's toy is sitting next to the child.

P.: It hints at your regress to childhood!

V.: Perhaps this happens due to my guilty behavior. I chose this picture as an illustration of thinking. It can be entitled "Suffering thinking"! A smiling face is a mask that I am wearing to mask...

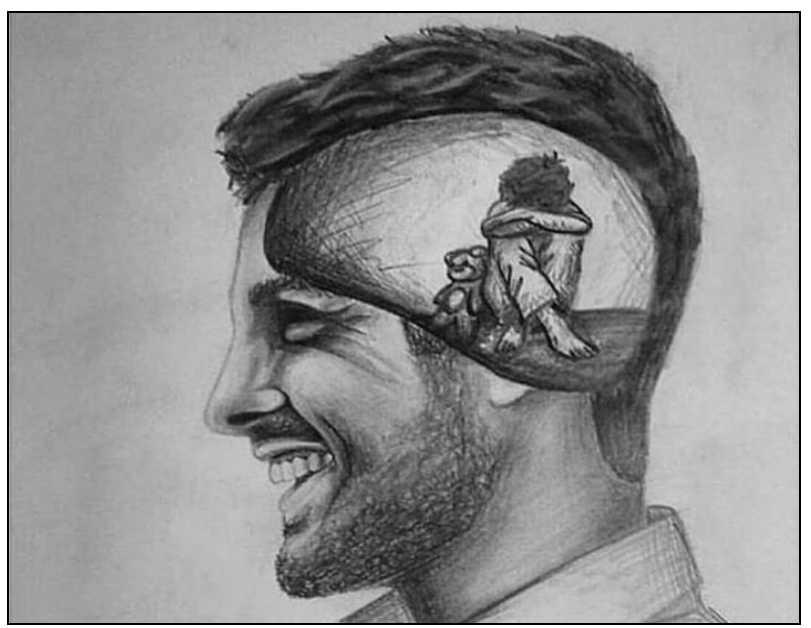

Fig. 26. The author and title are unknown The respondent's title is "Suffering Thinking" 
P.: The following picture 27 illustrates self-birth as if "from the ground." The Earth is an archetype of the mother, and here is a crater. You want to be self-born. I have only showed where you can inhibit yourself from this desirable development of selfbirth. Good luck!

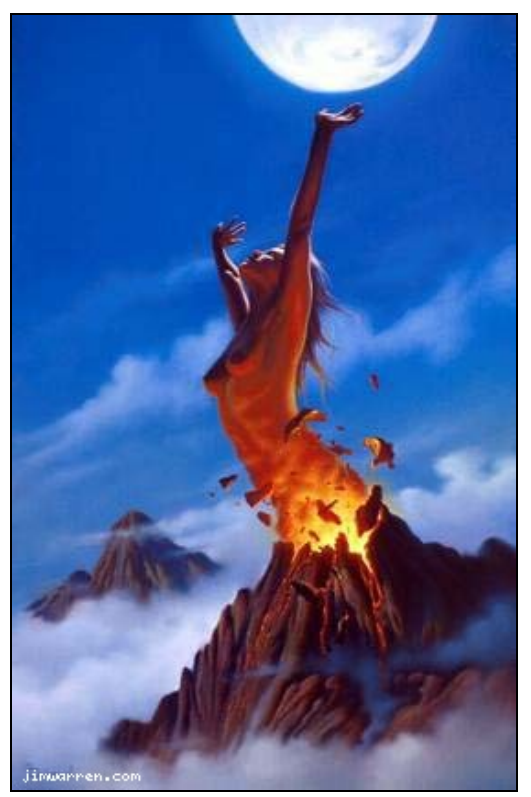

Fig. 27. J. Warren. Volcano girl

V. Thank you! Previously, I have had no idea about what I found out. Now I can self-reflect consciously. I will understand what tendencies I am captured by and where I am going to: either to the skeleton (Fig. 16), or turn back, into the womb and self-deprivation (Fig. 26). Sometimes I'm afraid if I find thy way out. Now, I will be more confident in life, because I realize that problems don't occur due to circumstances. I am keeping them current under the particular circumstances. After our session, I will be able to recognize my destructive tendencies and try to prevent their occurrence! I am sure that I will become calmer. This session gave me the opportunity to get free from the emotions that captured me. Thanks a lot! It is unforgettable and I am sure that my mind will work for me. It is my self-development and growing up on the way of self-realization.

Conclusions. The article "A person's behavioral destructions and their correction in the depth cognition of the psyche" objectifies the depth of the mutual influence of the family members on the formation of latent factors. These factors have the energetic influential potential on the harmonization of "mortido" and "libido "energy" in a person's behavior. The harmonization complexity of these energetic introjects has been complicated by their synthesis with the meanings given by the primary libido objects. Therefore, the introjects correction is complicated by the replacements effects of one or more of the primary libido objects. That is why the psycho-correctional reconstruction of the behavior is exposed to the libido objects separation. The latter is also associated with rigid behavior, which is interfering with a person's adaption in society. We have found out the tendencies of transferring the forms and style of relationships with the primary libido objects to a partner. The APSC fragment, presented in the work proves the possibilities of procedural diagnostics and correction while meeting the requirements of ration and multilevel implementation.

The aim of the diagnostic-correctional process consists in reorienting the mortido energy into the libido. The latter opens prospect of a person's approaching to a life-affirming position on the basis of self-perception and leveling of destructive tendencies which had been stipulated by fixations of the childhood period development.

The self-preservation instinct revival is being harmonized with the formation of diagnostic and correction abilities of self-help and auto-correction. It promotes social-perceptual intelligence development and opens the prospect of a comprehensive self-realization of inner potential.

\section{REFERENCES}

Bauer V., Dumots I., Golovin S. (1988) Энциклопедия символов, [Encyclopedia of symbols], 502 p. [in Russian]

Grof S. (2000) Космическая игра [Space game], 256 p. [in Russian]

Sacher-Masoch L. (1992) Венера в мехах [Venus in furs], 380 p. [in Russian]

Neumann, Е. (1998) Происхождение и развитие сознания [The origin and development of consciousness], 462 p. [in Russian]

Romenets V. А. (1993) Історія психології епохи Просвітництва [History of Psychology Enlightenment], 568 p. [In Ukrainian].

Romenets V. А. (1983) Історія психології Стародавнього світу і середніх віків [History of Psychology Ancient and Middle Ages], 416 p. [In Ukrainian].

Tatenko V. (2009) Сучасна психологія. Теоретикометодологічні проблеми [Modern psychology. Theoretical and methodological problems], 285 p. [In Ukrainian]. 
Fromm E. (2014) Анатомия человеческой деструктивности [Anatomy of human destructiveness], 810 p. [in Russian]

Furman A. V. (2016) Ідея і зміст професійного методологування [The idea and content of professional methodology], 376 p. [In Ukrainian].

Yatsenko T. S., Gluzman A. V., Meloyan A. E., Tuz L. G. (2010) Агрессия: психологическая теория и феноменология [Aggression: Psychological Theory and Phenomenology], 271 p. [in Russian]

Yatsenko T. S. (2008) Глибинна психологія: діагностика та корекція тенденції до психологічної смерті [Depth Psychology: Diagnosis and Correction of the Trends to Psychological Death], 204 p. [In Ukrainian].

Yatsenko T. S. (2015) Методология глубиннокоррекционной подготовки психолога [Methodology of depth-correctional preparation of a psychologist], 396 p. [In Russian].

Yatsenko T. S. (2016) Глибинне пізнання самодепривації психіки майбутнього психолога [Deep knowledge of the selfdeprevation of the future psychologist's psyche], 383 p. [In Ukrainian].

\title{
РУЙНУВАННЯ ПСИХІЧНОГО ТА ЙОГО РІВЕНЬ У ГЛИБИННОМУ ПІЗНАННІ
}

\author{
Яценко Тамара Семенівна \\ Доктор психологічних наук, професор, \\ Академік Національної академії педагогічних наук України, \\ Завідувач кафедри психологї̈, глибинної корекції та реабілітаціі \\ Черкаський національний університет імені Богдана Хмельницького \\ Черкаси (Украӥна)
}

Глибинне пізнання психіки, здійснене під час практики психодинамічного розуміння явища психічного, може об'єктивувати руйнування психіки людини, викликане дисфункціональними відносинами в сім'ї в межах трикутника: «батько - дитина мати». Резюме психоаналізу, представлений у цій статті, доводить не лише роль Едіпальних залежностей, які індукують відцентрову силу навколо порочного кола, але й об'єктивують руйнівні наслідки, які виражаються у розумовій відсталості людини, викликаючи порушення рівноваги між " енергії лібідо ”та“ Мортідо ”. У статті об'єктивовано основний конфлікт «життя-смерть», а також ризики порушення його балансу, що сприяє розвитку тенденцій до імпорту психіки та послаблення інстинкту самозбереження. Емпіричні докази, представлені у статті, усно та наочно доводять взаємозв'язок глибинних аспектів їх впливу на поведінкові, що спричиняють руйнування психіки, які потребують корекції у групах АСПК.

КЛЮЧОВІ СЛОВА: глибинна психологічна корекція, АSPC, руйнування, психіка, архаїзми.

РАЗРУШЕНИЕ ПСИХИЧЕСКОГО И ЕГО ВЫРАВНИВАНИЕ В ГЛУБИННОМ ПОЗНАНИИ Яценко Тамара Семеновна

Доктор психологических наук, профессор, Академик Национальной академии педагогических наук Украины, Заведующий кафедрой психологии, глубинной коррекции и реабилитации Черкасский национальный университет имени Богдана Хмельниикого

Черкассы (Украина)

Глубинное познание психики, осуществляемое при психодинамическом понимании феномена психического, может объективировать психические деструкции, вызванные дисфункциональными отношениями в семье в рамках треугольника: «отец - ребенок - мать». Резюме психоанализа, представленное в этой статье, доказывает не только роль эдиповых зависимостей, которые вызывают центробежную силу вокруг замкнутого круга, но также объективирует разрушительные последствия, которые выражаются в умственной отсталости человека, вызывая нарушения баланса между «энергии либидо» и «мортидо». Статья объективизирует основной конфликт «жизнь-смерть», а также риски нарушения его баланса, что способствует развитию тенденций к импорту психики и ослаблению инстинкта самосохранения. Эмпирические данные, представленные в статье, устно и наглядно подтверждают взаимосвязь глубинных аспектов в их влиянии на поведенческие, которые вызывают психические разрушения, нуждающиеся в коррекции в группах АСПК.

КЛЮЧЕВЫЕ СЛОВА: глубинная психологическая коррекция, ASPC, разрушения, психика, архаизмы. 